\title{
Analysis of a Hydrosuction Sediment Removal System for Tuttle Creek Lake, Kansas \\ by John Shelley
}

PURPOSE: Sediment accumulation in reservoirs displaces available water storage, increases operational difficulties and costs, and decreases reservoir benefits. Given the large volumes of sediment that annually accumulate in reservoirs, traditional methods for sediment management such as dredging with disposal into confined disposal facilities (CDF) are often cost prohibitive and impractical. This U.S. Army Corps of Engineers (USACE) Regional Sediment Management Technical Note (RSM-TN) presents analysis of a relatively low-cost hydrosuction sediment removal system for Tuttle Creek Lake in Kansas, USA.

INTRODUCTION: Tuttle Creek Lake is a large, multi-use USACE lake in Kansas (Figure 1) that provides significant benefits through its authorized purposes of flood control, water supply, navigation, water quality, recreation, and fish and wildlife. The multi-purpose pool of this reservoir is accumulating sediment at a rate of 5.8 million cubic yards per year (Mcy/year). As of 2009, the reservoir had lost $40 \%$ of its multi-purpose pool storage volume. The USACE Kansas City District (NWK) and the U.S. Department of Agriculture performed erodibility testing of the reservoir sediment deposits in 2015 and found that the new deposits are highly erodible, but the older, more consolidated deposits are up to 200 times less erodible. In other words, it is much less expensive to maintain storage now through intentional sediment management than to attempt to restore lost storage in the future.

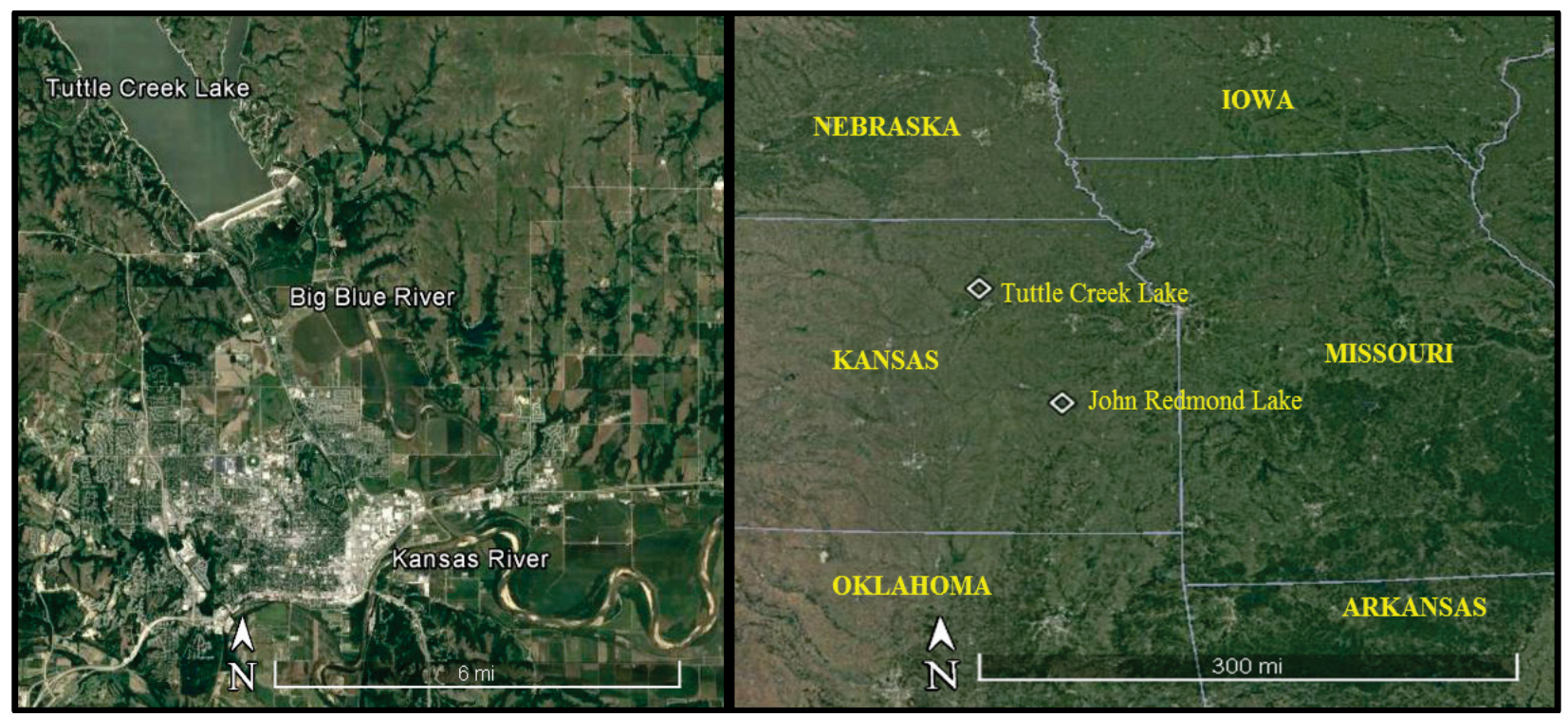

Figure 1. Tuttle Creek Lake and John Redmond Lake, KS. 
July 2019

A 2013 workshop with participants from the USACE, the State of Kansas, U.S. Geological Survey (USGS), and reservoir sedimentation experts from academia and industry identified hydrosuction as a promising option for managing sediment at Tuttle Creek Lake (Shelley 2015). A simplified analysis by McFall and Welp (2015) indicates that at the multi-purpose pool level, this sediment bypass scheme could remove sediment from an area close to the dam and pass it downstream at the annual rate of sediment accumulation in the reservoir. This simplified analysis generated tremendous interest when discussed with local stakeholders at a 2016 RSM workshop on nearby Milford Lake (Shelley and Boyd 2017) and in various presentations at local conferences. More robust analysis was needed to bring this idea to potential funding partners and to answer questions posed by regulatory agencies. This RSM-TN documents analysis on the long-term effectiveness of a hydrosuction sediment removal system for Tuttle Creek Lake. It presents an analysis of (a) effectiveness using historic pool elevations, (b) how effectiveness changes if the system is constrained to operate within the range of pre-dam sediment concentrations, and (c) how much sediment is available near the dam. It also lists potential alternatives and needs for further analysis.

COSTS FOR TRADITIONAL DREDGING: In 2016, the Kansas Water Office dredged 3 Mcy of material from nearby John Redmond Reservoir (Figure 2) at a cost of $\$ 20$ million or $\$ 6.67 /$ cy (KWO 2016). These costs included the dredging contract price and the price for some of the land used for sediment disposal. A portion of the land used for sediment disposal was donated by the USACE.

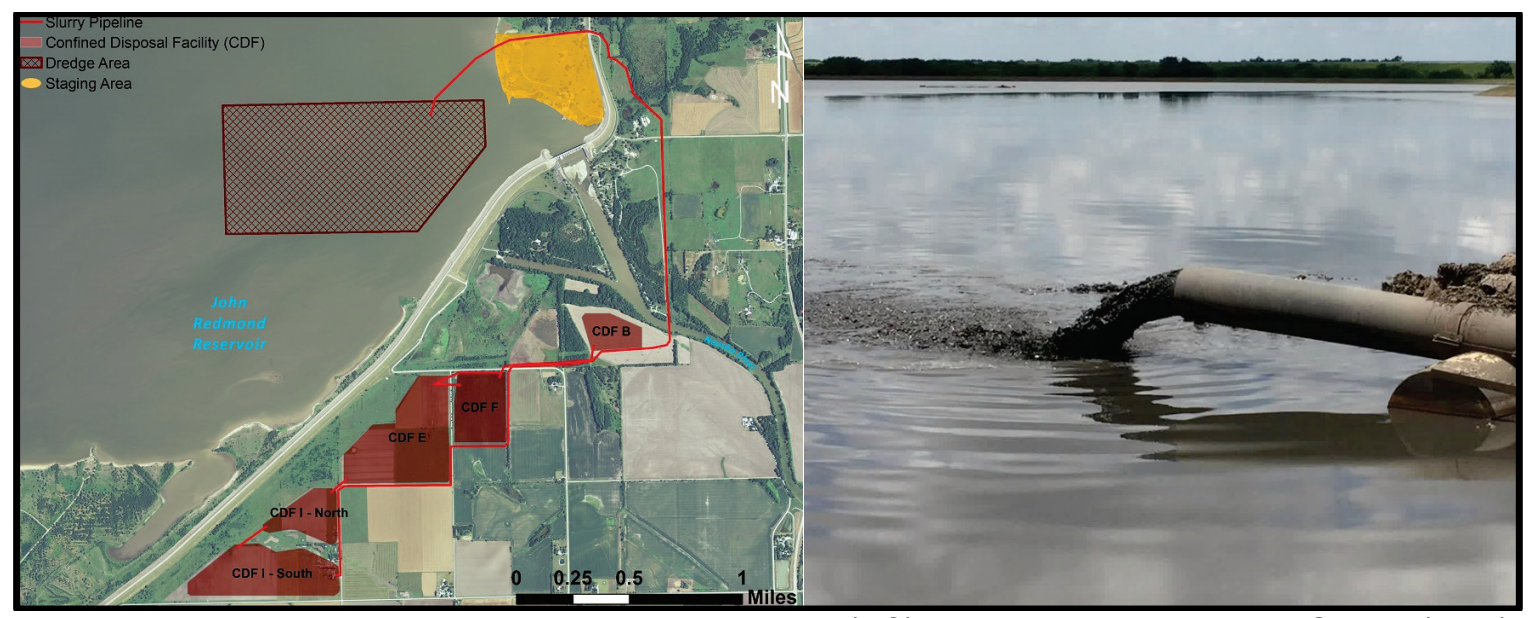

Figure 2. John Redmond Reservoir dredging diagram (left); dredging discharge into CDF E (right).

Based on the volume difference computed from hydrographic surveys in 1962 and 2009, the average sediment accumulation rate in the multi-purpose pool of Tuttle Creek Lake is approximately 5.8 Mcy/year. Assuming the same cost as the John Redmond Dredging Project (\$6.67/cy), dredging Tuttle Creek Lake would cost \$38.7 million/year. This represents the cost to keep pace with the rate of sediment accumulation but not to restore any previously lost storage. This number is likely conservative due to the higher cost of land near Tuttle Creek Lake compared to near John Redmond and because disposal costs would increase over time as closer, more accessible disposal sites are filled.

HYDROSUCTION: Given the large volume of accumulating sediment and the high cost for traditional dredging with upland disposal, the Kansas Water Office and the USACE have been looking for less expensive, more sustainable ways to manage sediment in Tuttle Creek Lake. During a workshop held August 2013 (Shelley 2015), state and federal participants identified 
hydrosuction as a promising option for passing sediment. This approach utilizes the head of water in the reservoir to power the removal, transport, and discharge of sediment to the downstream channel (Hotchkiss and Huang 1995). Hydrosuction is significantly less expensive than traditional dredging with upland disposal because it eliminates the costs for external power that typically comprise $30 \%$ of the cost of dredging operation, as well as the costs for upland disposal of the sediments, which can comprise over $50 \%$ of the total cost of a dredging operation (McFall and Welp 2015). Hydrosuction can be used with success to take sediment up and over small dams. However, in a tall dam like Tuttle Creek, the water would cavitate in the pipe before reaching the top of the dam.

McFall and Welp (2015) analyzed hydrosuction for Tuttle Creek going through the dam by connecting to the existing inlet structure. They estimate that two 2-foot (ft)-diameter (diam) pipes at Tuttle Creek Lake would be sufficient to pass between 4 and 8.4 Mcy of sediment per year. This is sufficient to reduce the trapping efficiency of Tuttle Creek Lake to 0. McFall and Welp assume (a) a connection to the existing inlet works, (b) sufficient deposited volume exists within 6,500 ft of the reservoir for continued operation, (c) a constant reservoir pool at the multi-purpose-pool level, (d) 6\% solids in the pipe, and (e) year-round operation regardless of the flow conditions in the downstream Big Blue River or Kansas Rivers. This RSM-TN re-analyzes hydrosuction in light of more robust analysis for each of these assumptions.

PHYSICAL LAYOUT: In a brainstorming session held 13 March 2017, NWK participants from geotechnical engineering, dam safety, geology, structures, river engineering, and cost estimating discussed the most feasible options for implementing a hydrosuction sediment removal system at Tuttle Creek Lake. This team discussed the option analyzed by McFall and Welp (2015), to attach the pipe to the existing conduit between the intake tower and the dam, as potentially less expensive. However, the team deemed this option non-constructible without draining the lake. The team deemed a second option, to drill a new conduit through the right abutment, as the most likely to be constructible and with the least potential problems from a dam safety perspective. Multiple options for suction pipe configurations and types exist that could influence effectiveness and cost. For purposes of computing effectiveness, two $2 \mathrm{ft}$ diam pipes are assumed. The first 3,500 $\mathrm{ft}$ of each pipe is assumed to be ductile iron with a fixed location, and the second 3,000 $\mathrm{ft}$ of each pipe is assumed to be rubber hose. Figure 3 depicts this configuration.

Previous hydrosuction projects with siphons have indicated that siphon pipelines are prone to debris blockages that interrupt operation. Furthermore, restarting such a large siphon could require significant, permanent design features and energy input. For these reasons, a hydrosuction system that is submerged, and therefore under positive pressure, was investigated rather than a siphon. This analysis does not assume any specific inlet configuration on the suction end of the pipe.

FLUID AND PIPE PROPERTIES: McFall and Welp (2015) assume $6 \%$ solids by volume in the pipe. A hydrosuction project in El Canada reservoir in Guatemala reported values that varied from $8 \%$ to $12 \%$ solids by volume in the pipe (Jimenez et al. 2015) using a proprietary water injection system to agitate sediments and increase the sediment removal. Selection of the inlet type is an important design step that can influence both the percent solids in the pipeline (and hence the project effectiveness) as well as the overall operability. 
July 2019

This RSM-TN presents results for three different levels of solids in the pipeline: $6 \%, 8 \%$, and $12 \%$. The density of the sediment slurry is computed with Equation 1 expressed in slugs per cubic foot (slugs $/ \mathrm{ft}^{3}$ ), and the dynamic viscosity of the sediment slurry is computed from Equation 2 expressed in pound-seconds per square foot $\left(\mathrm{lb}-\mathrm{sec} / \mathrm{ft}^{2}\right)$. Table 1 presents fluid properties assuming $6 \%, 8 \%$, and $12 \%$ solids. The water temperature is assumed to be $59^{\circ} \mathrm{F}$, which is the average water temperature from U.S. Geological Survey (USGS) Gage \#6887000, Big Blue River near Manhattan, KS, located approximately 2.4 miles downstream from the dam.

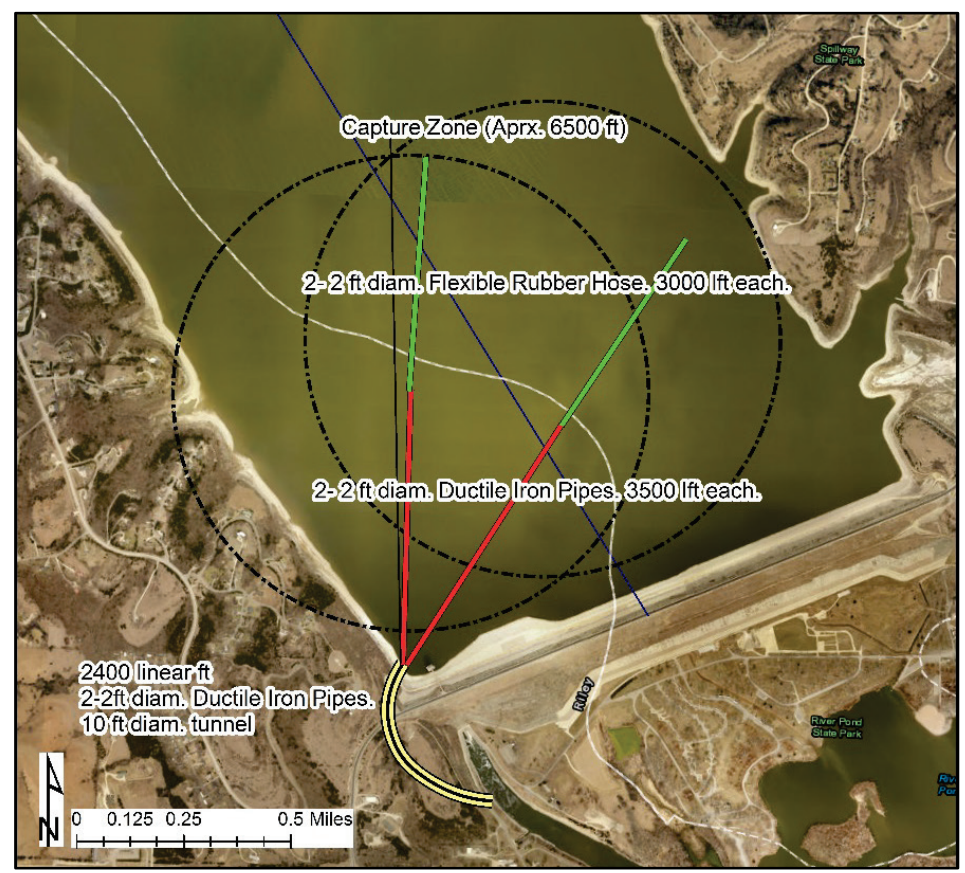

Figure 3. Hydrosuction configuration under analysis. (aerial photo source: ESRI 2013)

$$
\begin{aligned}
& \rho=[(1-\varphi)+2.64 \varphi](62.4)(0.031081) \\
& \mu=\mu_{w}\left(1+2.5 \varphi+14.1 \varphi^{2}\right)
\end{aligned}
$$

where:

$$
\begin{aligned}
& \left.\rho=\text { density of the sediment slurry ( } \text { slugs } / \mathrm{ft}^{3}\right) \\
& \Phi=\text { solids fraction by volume (dimensionless) } \\
& \mu_{w}=\text { dynamic viscosity of the water }\left(\mathrm{lb}-\mathrm{sec} / \mathrm{ft}^{2}\right) \\
& \mu=\text { dynamic viscosity of the sediment slurry }\left(\mathrm{lb}-\mathrm{sec} / \mathrm{ft}^{2}\right) .
\end{aligned}
$$

Table 1. Fluid properties of the discharge slurry at 6,8 , and $12 \%$ solids.

\begin{tabular}{||l|l|l|l|l||}
\hline Solids Fraction & 0.06 & 0.08 & 0.12 & \\
\hline Density of Slurry & 2.13 & 2.20 & 2.32 & slugs/ $/ \mathrm{ft}^{3}$ \\
\hline Dynamic Viscosity of Water $\left(\mu_{w}\right)$ & $2.38 \mathrm{E}-05$ & $2.38 \mathrm{E}-05$ & $2.38 \mathrm{E}-05$ & $\mathrm{lb}-\mathrm{sec} / \mathrm{ft}^{2}$ \\
\hline Median Grain Size & 0.002 & 0.002 & 0.002 & millimeters \\
\hline \hline
\end{tabular}


Pipe lengths and types are presented in Table 2. Components contributing to minor losses are included in Table 3.

\begin{tabular}{|l|l|c|c|c||}
\hline \multicolumn{4}{||l}{ Table 2. Fluid properties of the discharge slurry at 6\%, 8\%, and 12\% solids. } \\
\hline \hline Material & Type & Length (ft) & Diameter (ft) & Pipe Roughness (ft) \\
\hline \hline Suction Pipe & Rubber Tubing & 3000 & 2 & 0.00013 \\
\hline Suction Pipe & Ductile Iron & 3500 & 2 & 0.0003 \\
\hline Discharge Pipe & Ductile Iron & 2400 & 2 & 0.0003 \\
\hline Suction Pipe & Rubber Tubing & 3000 & 2 & 0.00013 \\
\hline
\end{tabular}

\begin{tabular}{|l|c|}
\hline \hline Table 3. Minor losses. \\
\hline \hline Component & $\begin{array}{c}\text { Loss Coefficient } \\
(\mathrm{K})\end{array}$ \\
\hline Entrance & 1.5 \\
\hline $90^{\circ}$ elbow & 0.3 \\
\hline $45^{\circ}$ elbow & 0.2 \\
\hline Valve & 2 \\
\hline Exit & 1 \\
\hline Total & 5.5 \\
\hline \hline
\end{tabular}

The Bernouli equation with the Swamee Jain approximation for friction, using the fluid and pipe properties given in Tables 1, 2, and 3, was used to calculate water discharge for a range of pool elevations. The sediment discharge for a given pool elevation was then computed as the percent solids times the water discharge at that pool elevation. Figure 4 provides the water discharge in cubic feet per second (cfs) over a range of pool elevations for $6 \%, 8 \%$, and $12 \%$ solids. Figure 5 displays the sediment discharge (cubic feet per second) versus pool elevation rating curve at $6 \%$, $8 \%$, and $12 \%$ solids for a single pipe.

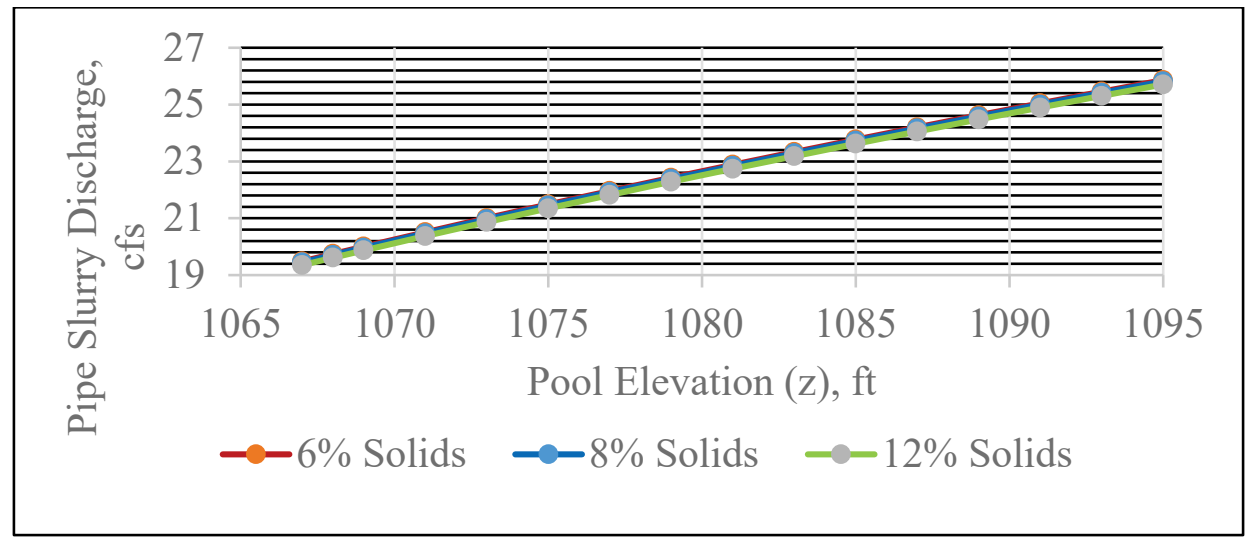

Figure 4. Water discharge (cubic feet per second) rating curves for a Tuttle Creek hydrosuction sediment removal system, single pipe. 
July 2019

LONG-TERM EFFECTIVENESS: McFall and Welp (2015) assumed a constant reservoir pool at the multi-purpose pool level. The actual pool level fluctuates during the year in response to flood inflows, seasonal operating pool levels, and downstream flow targets and constraints. For this RSMTN, the historic values for pool elevation since 01 October 1963 to 30 September 2016 were used to generate a more realistic estimate for sediment removal (Figure 6). The equations in Figure 5 allow the transformation of the period of record of daily pool elevations into a daily series of sediment transport rates. Summing the daily sediment transport volumes over the period of record and dividing by the number of years allows the computation of the long-term annual discharge rate.

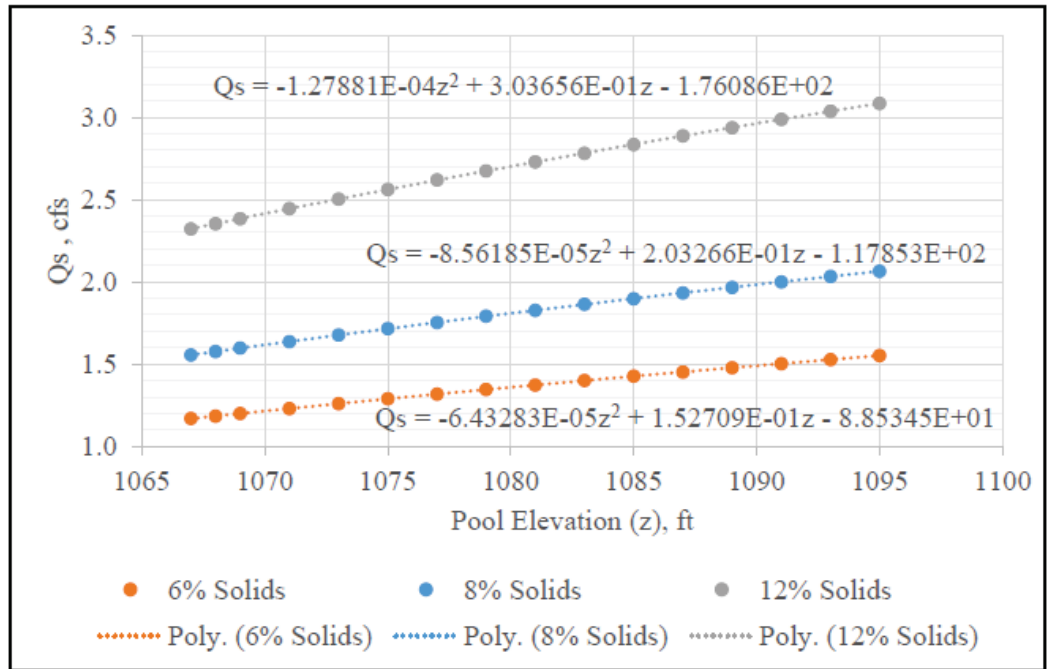

Figure 5. Sediment discharge (cubic feet per second) rating curves for a Tuttle Creek hydrosuction sediment removal system, single pipe.

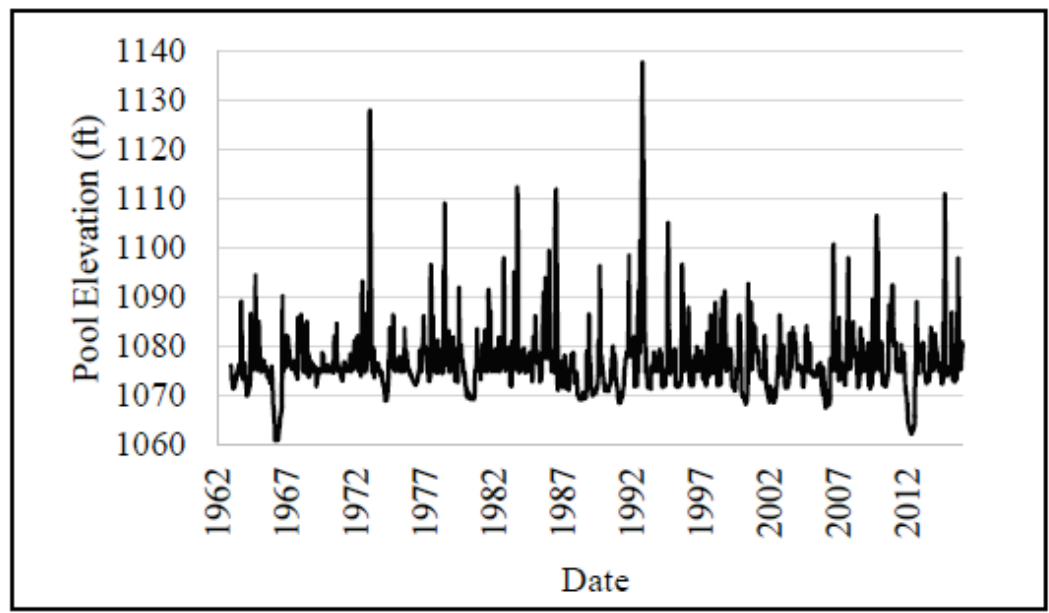

Figure 6. Time series of daily pool elevations, 01 October 1962 to 30 September 2016.

Table 4 presents the results for two pipes, assuming the hydrosuction system operates $100 \%$ of the time. The percent of annual accumulation represents the percent of the accumulation rate in the multi-purpose pool only (not the flood pool). 


\begin{tabular}{|c|c|c|}
\hline \multirow{2}{*}{ Solids Fraction } & \multicolumn{2}{|c|}{ Average Annual Sediment Discharge } \\
\hline & Mcy & $\%$ of Annual Accumulation \\
\hline 0.06 & 3.1 & $53 \%$ \\
\hline 0.08 & 4.1 & $70 \%$ \\
\hline 0.12 & 6.1 & $105 \%$ \\
\hline
\end{tabular}

As seen in Table 4, the system is estimated to remove $53 \%-105 \%$ of the annual sediment accumulation, depending on the percent solids in the pipelines.

ENVIRONMENTAL CONSTRAINTS: The above analysis assumed operation 24 hours per day, 7 days per week. However, environmental considerations may prohibit discharging sediment during periods of low flow on the downstream Big Blue River. While the concentration in the discharge pipe is assumed constant at $6 \%, 8 \%$, or $12 \%$ solids, the concentration in the downstream Big Blue River varies over several orders of magnitude depending on the rate of discharge of clear water from Tuttle Creek Dam. Figure 7 plots the concentration in the Big Blue River under a hydrosuction bypass scheme with $6 \%, 8 \%$, or $12 \%$ solids against the discharge in the Big Blue River. The concentration in the Big Blue River is a function of the flow and sediment in both the hydrosuction discharge and the current sediment concentrations. Figure 7 also plots the suspended sediment concentrations for the three major tributaries to Tuttle Creek Lake (Black Vermillion, Big Blue, and Little Blue). The concentrations of sediment in the inflows to Tuttle Creek Lake provide a reasonable upper bound for increased sediment as an ecologically restorative activity.

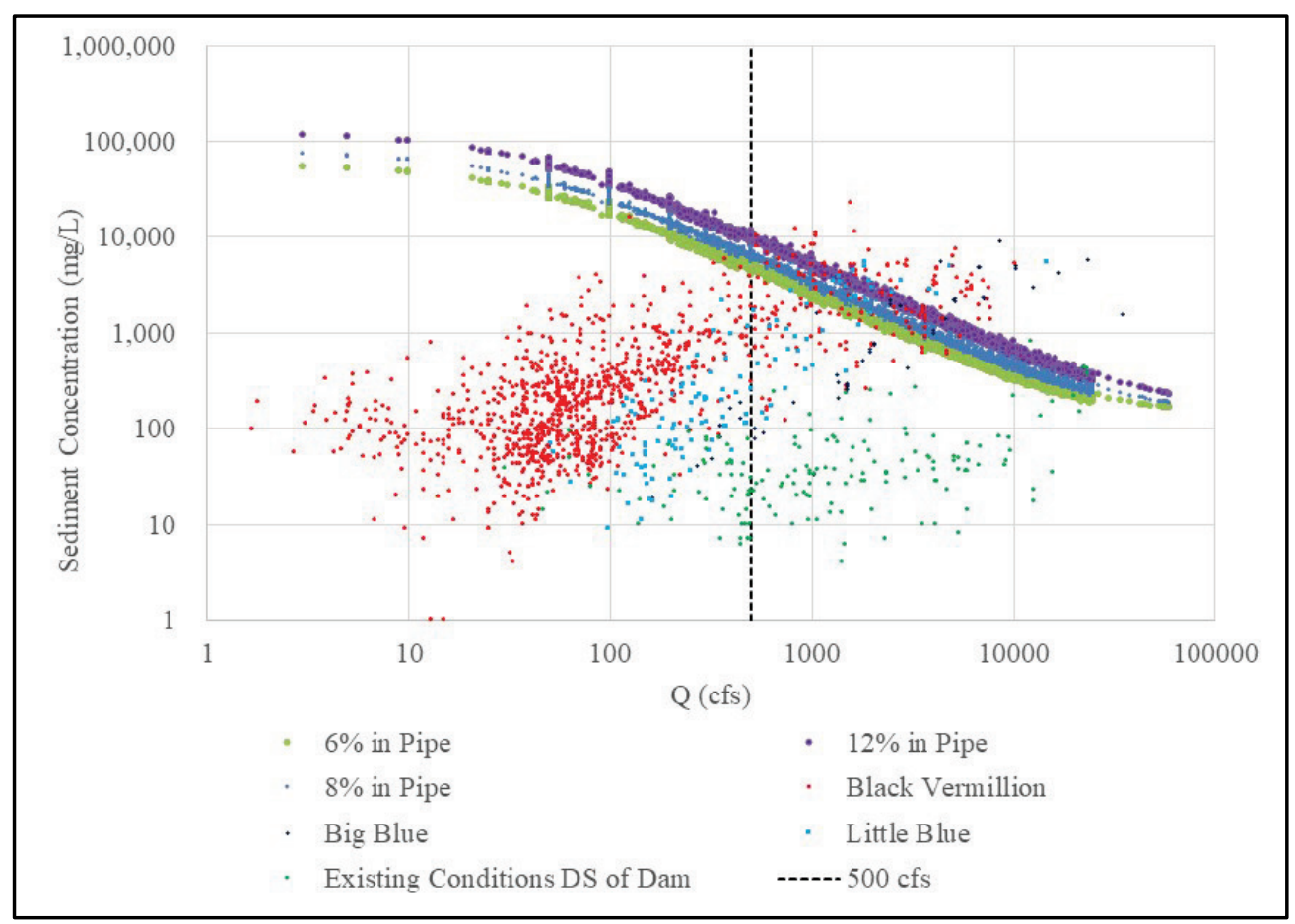

Figure 7. Post-project sediment concentrations on Big Blue River compared to predam sediment concentrations (based on USGS Gage \#6886000: Big Blue River at Randolph, 1942 to 1959). 
July 2019

Figure 7 indicates that with two pipes and 6\% solids in the pipe, at flows above approximately $500 \mathrm{cfs}$ the hydrosuction system will not induce sediment concentrations in excess of the range of incoming sediment concentrations. Over the period of record, gate releases have fallen below $500 \mathrm{cfs} 26 \%$ of the days. Only allowing hydrosuction when flows exceed this threshold would equate to downstream sediment levels near the upper range of the maximum incoming levels at flows near $500 \mathrm{cfs}$ and decreasing concentrations as flow increases. As indicated in Figure 7, significantly more sediment discharge at high flows is possible within the concentration constraints, but such increases are not possible with the hydrosuction system alone. A dredging solution could provide the additional power needed to pass more sediment during high flows.

More stringent (higher) flow thresholds would lead to more days with relatively clear water discharges and a reduced ability to achieve reservoir sustainability and sediment continuity. Table 5 presents the results for average annual sediment discharge for a hydrosuction system that only operates on days with flows in the Big Blue River at or above 500, 1,000, and 2,000 cfs. This analysis pertained to the Big Blue River. Potential impacts to the Kansas River downstream of the Big Blue River are discussed later in this RSM-TN.

To achieve long-term sustainability, the hydrosuction system must remove $100 \%$ of the incoming sediment. Table 5 indicates that hydrosuction alone, subject to the concentration constraint of not operating below $500 \mathrm{cfs}$, is not sufficient to achieve long-term sustainability.

\begin{tabular}{|c|c|c|c|c|}
\hline \multirow{3}{*}{ Solids Fraction } & \multicolumn{4}{|c|}{ Flow Threshold (cfs) } \\
\hline & 0 & 500 & 1000 & 2000 \\
\hline & \multicolumn{4}{|c|}{ Mcy (\% of Annual Accumulation) } \\
\hline 0.06 & $3.1(53 \%)$ & $2(34 \%)$ & $1.3(23 \%)$ & $0.8(14 \%)$ \\
\hline 0.08 & $4.1(70 \%)$ & $2.6(45 \%)$ & $1.7(30 \%)$ & $1.1(18 \%)$ \\
\hline 0.12 & $6.1(105 \%)$ & $3.9(67 \%)$ & $2.6(44 \%)$ & $1.6(27 \%)$ \\
\hline
\end{tabular}

DEPOSITED VOLUME: The effectiveness of each option depends, among other things, on the distance between where the sediment is entrained and where it is discharged. The closer to the dam, the less friction loss in the pipe and the more effective the hydrosuction is at removing sediment. Figure 8 indicates the total cumulative deposited sediment volume from 1962 to 2009. The analysis in this RSM-TN assumes the sediment is removed from a distance within 6,500 $\mathrm{ft}$ of the dam. Within this $6,500 \mathrm{ft}$ closest to the dam, 14.4 Mcy of sediment deposited from 1962 to 2009, or approximately $0.31 \mathrm{Mcy} /$ year. Within the 30,000 ft closest to the dam, $68.1 \mathrm{Mcy}$ of sediment deposited from 1962 to 2009 , or approximately $1.4 \mathrm{Mcy} / \mathrm{year}$.

Assuming the historic rate of sediment accumulation continues, with no sediment removal the lower $6,500 \mathrm{ft}$ of reservoir will have accumulated 32.1 Mcy by 2067. Assuming a conservatively low $\$ 6.67$ per cubic yard (cy), removing this quantity of sediment via dredging with upland disposal would cost $\$ 214$ million. In the lower 31,000 ft of reservoir, 152.1 Mcy will have accumulated by 2067 . At $\$ 6.67 / \mathrm{cy}$, removing this quantity of sediment via dredging with upland disposal equates to just over $\$ 1$ billion. The real cost would be much higher, due to the lack of accessible land close to the dam sufficient for storing such a large quantity of sediment. 


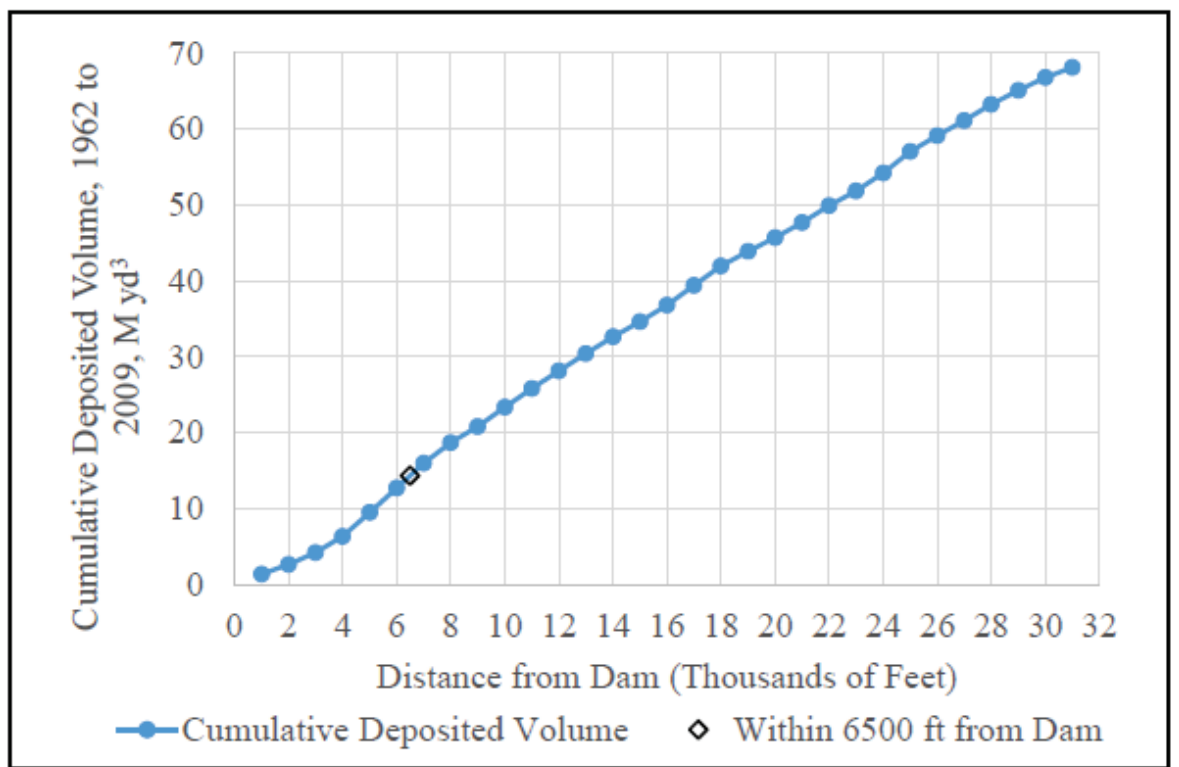

Figure 8. Cumulative deposited volume above Tuttle Creek Lake dam.

While any excavated hole will eventually re-fill, for the lower $6,500 \mathrm{ft}$ the rate of infilling is most likely less than the rate of sediment removal. Figure 9 plots the sediment storage in the $6,500 \mathrm{ft}$ closest to the dam over time, assuming hydrosuction at $6 \%, 8 \%$, and $12 \%$ solids that only operate when gate releases exceed $500 \mathrm{cfs}$. In Figure 9, the sediment is assumed to refill at the historic rate of deposition in the lower $6,500 \mathrm{ft}$ of $0.31 \mathrm{Mcy} /$ year. Likely, this rate would be accelerated as nearby sediments flow into the scour holes, making the estimates in Figure 9 conservative (sediment will be exhausted later than shown). As seen in Figure 9, the hydrosuction system can operate at $6,500 \mathrm{ft}$ from the dam for $4.3,6.0$, and 8.9 years before exhausting the available sediment (for $12 \%, 8 \%$, and $6 \%$ solids in the pipeline, respectively). At this point in time, sediments close to the dam will be exhausted, and the system will have to move farther upstream (at an efficiency cost) to continue functioning without lowering the reservoir bed below pre-impoundment elevations. Figure 10 depicts the approximate efficiency costs when removing sediments from distances farther than 6,500 ft away from the dam. As seen in Figure 10, the efficiency of the hydrosuction system decreases with distance from the dam. At 31,000 ft, the system removes sediment at $52 \%$ the rate it removes sediment from the first $6,500 \mathrm{ft}$. 


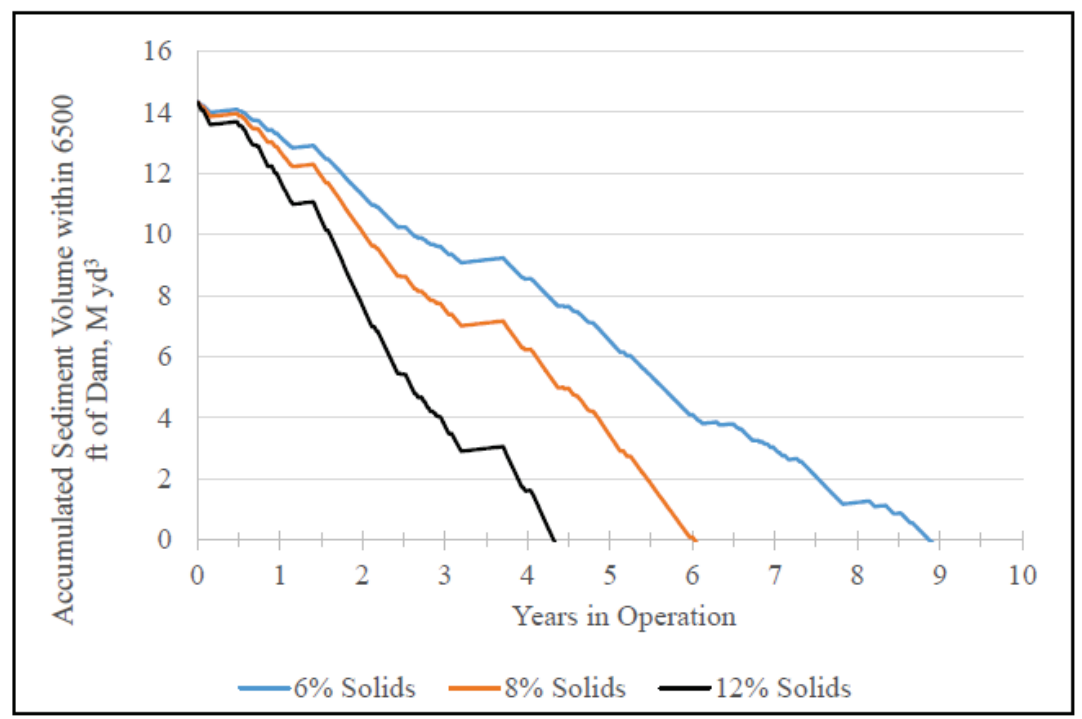

Figure 9. Accumulated sediment in the $6,500 \mathrm{ft}$ closest to Tuttle Creek Lake dam.

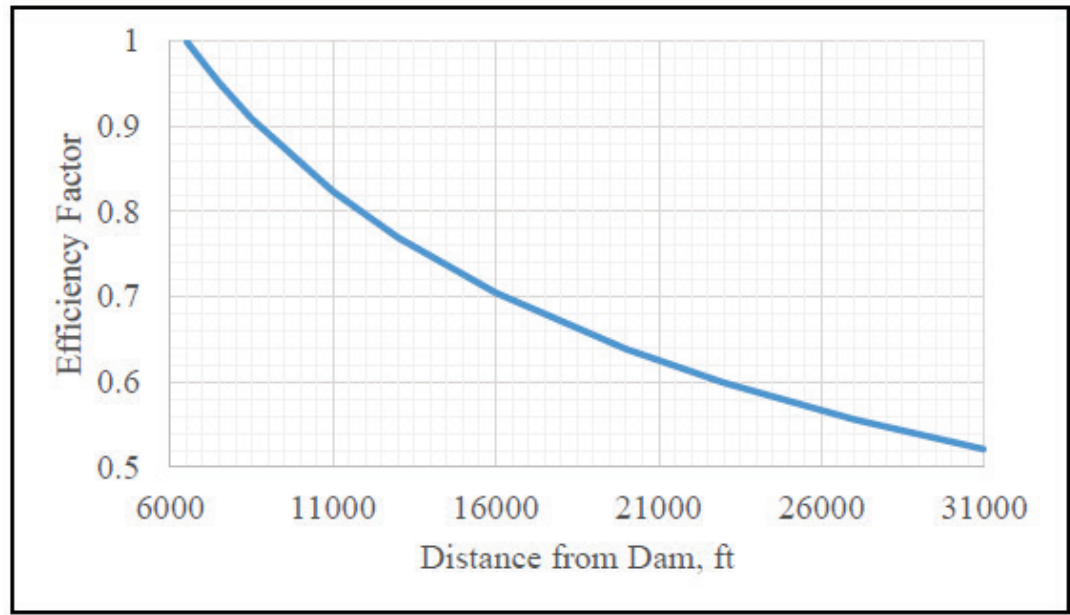

Figure 10. Efficiency reduction with distance from the dam, compared to the sediment removal rate at $6,500 \mathrm{ft}$ from the dam.

Rather than chasing the problem upstream, methods to accelerate the refilling of suction holes with sediments farther upstream in the reservoir could be employed. Such methods could include "water injection dredging" (Bronscoort 2013) or partial drawdown flushes to redistribute sediment. Further analysis of the technical feasibility and impacts of such methods is recommended.

\section{EFFECT ON KANSAS RIVER GEOMORPHOLOGY, ECOLOGY, and WATER USERS:} Shelley et al. (2016) indicate sediment trapping by Tuttle Creek, Milford, Kanopolis, Wilson, Harlan County, and Wakunda Lakes totals 13 Mcy/year. Table 5 indicates up to $3.9 \mathrm{Mcy} / \mathrm{year}$ of sediment restoration may be achieved by a hydrosuction system operating at flows higher than 500 cfs. Therefore, even with hydrosuction installed at Tuttle Creek Lake, the Kansas River would still be much clearer than it would be in a no-dam condition.

Juraceck and Mau (2002) note that 98\% of the sediment deposited in Tuttle Creek Lake is clay. The coarse sediments are almost exclusively depositing in the upstream delta rather than close to the dam. Subsequent data collection has confirmed predominantly clay sediments with some silt, 
some organic material, and very little sand downstream from the delta. The hydrosuction system analyzed in this RSM-TN only removes and passes sediments that are located close to the dam.

Velocities in the Kansas River are sufficient to prevent the deposition of silt and clay sediments in the river bed, as evidenced by the lack of fines in river bed sediment samples (SLA 1984). An increased discharge of fine sediments will not induce significant geomorphic change in the Kansas River. This is particularly true if sediments are only released when flow in the Big Blue River exceeds $500 \mathrm{cfs}$. A feasibility-level study of sediment management at Tuttle Creek Lake should include a quantification of changes to suspended sediment concentration in the downstream channel for each alternative.

The increased discharge of fine sediments from Tuttle Creek Lake will partially restore suspended sediment concentrations on the downstream Kansas River, which could benefit native fish species. A lack of turbidity has led to population declines in several native species of fish in the Kansas River, including shoal chub, plains minnow, flathead chub, river shiner, and carmine shiner. These have been replaced by sight-feeding fish less tolerant to turbid water. A summary of research documenting the effects of decreased turbidity on the fish species in the Kansas River is provided in Shelley et al. (2016).

Major municipalities depend on the Kansas River for water supply, including Manhattan, Topeka, Lawrence, Olathe, and Johnson County (the west side of the Kansas City metro area). These water users are primary beneficiaries of the storage in Tuttle Creek Lake and will be significantly impacted by continued storage loss. However, these same water users may have to modify or increase water treatment at their facilities to accommodate increased suspended sediment concentrations in the Kansas River if hydrosuction were implemented at Tuttle Creek Lake. Feasibility-level analysis of hydrosuction at Tuttle Creek Lake must include consideration and involvement of the downstream water users.

DAM SAFETY CONSIDERATIONS: This RSM-TN did not evaluate the dam safety implications of a hydrosuction sediment removal system. Prior to approval for any dam modification, a detailed failure modes analysis would need to be conducted, the results of which could preclude or modify the options discussed in this RSM-TN.

ALTERNATIVES/ADDITIONS TO HYDROSUCTION: This RSM-TN analyzed the effectiveness of a single hydrosuction alternative (i.e., taking two $2 \mathrm{ft}$ diam pipes through the right abutment). Based on the insufficiency of this option to achieve complete sediment continuity (and hence long-term sustainability) and the lack of sufficient material close to the dam for long-term operation, the following alternatives are suggested for further study and comparison:

1. Hydrosuction as in this RSM-TN, designed to be converted in future years to a dredging operation with downstream discharge of sediments.

2. A hybrid dredging/hydrosuction system, where one pipe operates by hydrosuction to remove sediments close to the dam and the other pipe operates via dredging and booster pumps to increase the concentrations of sediment during high flows and access sediments further from the dam.

3. A dredging operation with downstream discharge of sediments where the pipe travels up and over the dam or abutment rather than through. 
July 2019

4. Water injection dredging to cause more sediments to flow to the existing outlet without hydrosuction or dredging.

5. Water injection dredging to accelerate the re-filling of the scour holes caused by hydrosuction or dredging.

All of these options are likely less expensive than the cost of traditional dredging with upland disposal of the sediments. More thorough analysis, including cost estimating, dam safety analyses, and downstream impacts of each option is necessary before an optimum solution can be determined.

CONCLUSION: This Regional Sediment Management Technical Note (RSM-TN) analyzed the effectiveness of a hydrosuction sediment removal system for passing sediment from Tuttle Creek Lake to the downstream Big Blue River. It was found that two $2 \mathrm{ft}$ diam pipes would be sufficient to remove and pass between 2 and 3.9 Mcy/year of sediment if only accessing sediment from the lower $6,500 \mathrm{ft}$ of the reservoir and only operating when gate releases are at least $500 \mathrm{cfs}$. The hydrosuction sediment removal system analyzed in this RSM-TN can remove a significant percentage of the accumulating sediment load. However, additional sediment removal will be required to achieve complete sediment continuity and long-term reservoir sustainability.

ADDITIONAL INFORMATION: This RSM-TN was prepared by Dr. John Shelley, hydraulic engineer at the USACE Kansas City District (NWK). The study was conducted as an activity of the USACE National Regional Sediment Management (RSM) Program, a Navigation Research, Development, and Technology (RD\&T) portfolio program administered by Headquarters (HQ) USACE. For information on the RSM Program, please consult http://rsm.usace.army.mil or contact the USACE National RSM Program Manager, Dr. Katherine Brutsche, U.S. Army Engineer Research and Development Center (ERDC), Coastal and Hydraulics Laboratory (CHL), at Katherine.E.Brutsche@usace.army.mil. For information regarding this RSM-TN, please contact John Shelley, john.shelley@usace.army.mil.

This Regional Sediment Management Technical Note (RSM-TN) should be cited as follows:

Shelley, J. E. 2019. Analysis of a Hydrosuction Sediment Removal System for Tuttle Creek Lake, KS. ERDC/TN RSM-19-5. Vicksburg, MS: U.S. Army Engineer Research and Development Center. https://hdl.handle.net/11681/33583

\section{REFERENCES}

Bronscoort, K. 2013. Sedimentation in Reservoirs: Investigating Reservoir Preservation Options and the Possibility of Implementing Water Injection Dredging in Reservoirs. Master of Science thesis. Technical University, Delft, Netherlands.

Hotchkiss, R., and X. Huang. 1995. "Hydrosuction Sediment Removal Systems (HSRS): Principles and Field Test." Journal of Hydraulic Engineering 121(6): 479-489.

Jimenez, A., R. Figueroa, and T. Jacobsen. 2015. Dredging of Cohesive Sediments with SediCon Dredge in El Canada Hydropower Plant, Guatemala. Commission International Des Grands Barrages. Congress Des Grands Barrages. Guatemala.

Juracek, K. E., and D. P. Mau. 2002. Sediment Deposition and Occurrence of Selected Nutrients and Other Chemical Constituents in Bottom Sediment, Tuttle Creek Lake, Northeast Kansas, 1962-1999. Water Resources Investigations Report 02-4048. Lawrence, KS: U.S. Geological Survey. 
Kansas Water Office (KWO). 2016. John Redmond Reservoir Dredging Fact Sheet. Topeka, KS: Kansas Water Office. http://www.kwo.org/Projects/JRDredging/JRRD\%20Fact $\% 20$ Sheet.pdf

McFall, B., and T. Welp. 2015. Tuttle Creek Siphon Dredging Investigation. ERDC/CHL LR-15-6. Vicksburg, MS: U.S. Army Engineer Research and Development Center.

Shelley, J. 2015. Reservoir Sediment Management Workshop for Tuttle Creek Lake and Perry Lake Reservoirs in the Kansas River Basin. ERDC/CHL CHETN-XIV-43. Vicksburg, MS: U.S. Army Engineer Research and Development Center.

Shelley, J., M. Boyer, J. Granet, and A. Williams. 2016. Environmental Benefits of Restoring Sediment Continuity to the Kansas River. ERDC/CHL CHETN-XIV-50. Vicksburg, MS: U.S. Army Engineer Research and Development Center.

Shelley, J., and P. Boyd. 2017. Reservoir Sediment Management Workshop for Milford Lake in the Kansas River Basin. ERDC/TN RSM-17-3. Vicksburg, MS: U.S. Army Engineer Research and Development Center.

Simons, L., and Associates (SLA). 1984. Analysis of Channel Degradation and Bank Erosion in the Lower Kansas River. MRD Sediment Series No 35. Kansas City, KS: U.S. Army Engineer District, Kansas City.

NOTE: The contents of this technical note are not to be used for advertising, publication, or promotional purposes. Citation of trade names does not constitute an official endorsement or approval of the use of such products. 